\title{
Leaching Behavior of Heavy Metals in Coal Gasification Residuals
}

\author{
Jialin Liu, Haibin He, Yumo Chen, Xueting Sun, \\ Jiaxing Zheng, Shasha Yang, Jianli Jia* \\ School of Chemical and Environmental Engineering, China University of Mining and Technology, \\ Beijing 100083, China
}

Received: 19 January 2017

Accepted: 12 March 2017

\begin{abstract}
The system of dynamic leaching was designed for samples of a coal gasification residual from a coalto-methanol plant in northwestern China in order to investigate the leaching behavior of four potentially hazardous elements - $\mathrm{Hg}, \mathrm{Cr}, \mathrm{As}$, and $\mathrm{Pb}$ - in the coal gasification residual and investigate the impacts of the leaching time, size of the samples, and $\mathrm{pH}$ of the leaching solution on the leaching behavior of elements. The concentrations of elements in the leachate samples were all determined by inductively coupled plasmamass atomic spectrometry (ICP-MS). The results showed that the leaching time, size of the samples, and $\mathrm{pH}$ of the leaching solution played an important role in affecting the leaching behavior of the selected elements from the coal residual samples. All trends were in decreasing order of significance as the leaching time went on and most leached concentrations reached the maximum at the initial stage of leaching experiments (from hours 0 to 4 ) accounting for $94.44 \%$. The 80 -mesh sample had the different leaching curve from the 10-mesh and 40-mesh samples for the same element because different forms of the heavy metals existed on the different-size samples.
\end{abstract}

Keywords: leaching behavior, influential factors, coal gasification residual, dynamic leaching system, heavy metal

\section{Introduction}

Coal is China's main source of energy, accounting for $47 \%$ of the world's total annual coal consumption [1]. And the coal industry will remain a significant part of manufacturing in the next decades, which has shown us we should focus more on rational exploitation and comprehensive use of coal resources. With the rapid development of the Chinese economy and the coal industry, an increasing number of industrial solid wastes

*e-mail: jj1@cumtb.edu.cn including fly ash, cinder, and coal gangue could lead to a series of environmental issues and human health problems during coal mining and processing [2-3].

Coal industry residue consists of fly ash and coal gasification residual. The disposal technology of fly ash has been quite mature. But there is no disposal method for coal gasification residue because of its low calorific value, large amount, large particle diameter, and high contents of heavy metals and PAHs [4-7]. At present, the main way of dealing with coal gasification residual is still, open dumping, which not only damages land resources but also destroys area scenery, even contaminating surrounding areas. Leaching has proven to be the most 

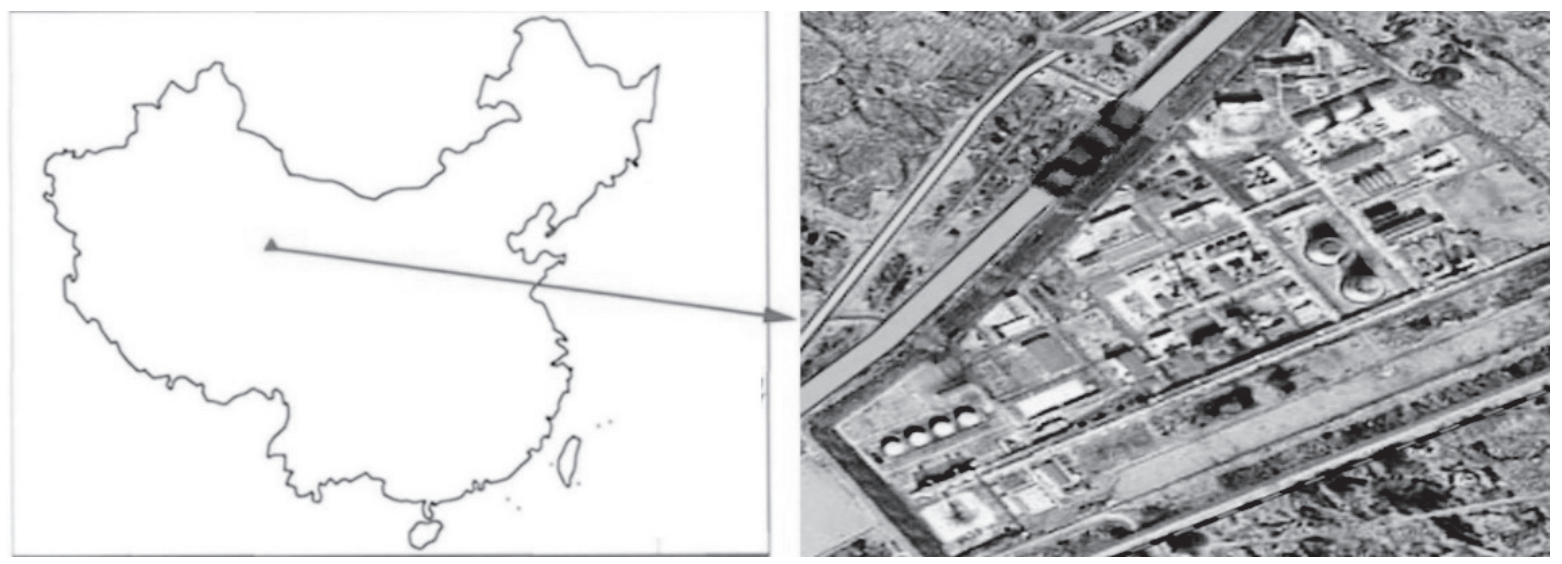

Fig. 1. Geographical location of a coal-to-methanol plant in northwestern China.

important of the primary pathways for toxic substances entering soil and water (even groundwater). Environmental pollution problems and the potential risks for human health are caused as a result of the release and migration of harmful elements contained in coal gasification residual. According to Liu Yang et al. [8], the leaching time and sample mass have a major impact on leaching behavior, and leaching has a high potential risk to groundwater.

Combining the research situation over the world, very little research about the comprehensive utilization of coal gasification residual has been done. Meanwhile, many studies on the disposal methods of fly ash and coal gangue, which may be easier to handle, have been carried out by other authors. These applications include concrete and cement products, structural fill, cover materials [9-11], and adsorption materials for removing pigment, organic compounds, and heavy metals [1217]. However, studies focused on the coal gasification residual are relatively rare - especially on the leaching behavior and environmental hazards. Therefore, this study was conducted to investigate the leaching behavior of four heavy metals from coal gasification residual. And the impact factors - including leaching time, $\mathrm{pH}$ of the leaching solution, and the size of the coal gasification residual sample - were simultaneously analyzed. The research can provide an important scientific basis for site assessment, monitoring, and remediation of the polluted area by the coal industry.

\section{Materials and Methods}

\section{Sample Collection}

Coal gasification residual samples were taken in a coal-to-methanol plant in northwestern China
(N38 34'41.9", E109 55'50.4”) (Fig. 1). The plant is located in the northernmost part of Shanxi Province, which includes the juncture of the Loess Plateau and Maowusu Desert. The study area has a semi-arid continental monsoon climate that features being rich in light energy, where the rainy season meets the hot season, and large temperature differences. As a result of being landlocked, the annual average temperature is $7.9-11.3^{\circ} \mathrm{C}$, and this is the area of lightest rainfall in Shanxi, with mean annual rainfall of approximately $316-513 \mathrm{~mm}$.

The great potential economic value of mineral resources reached 43 trillion yuan, accounting for 95 percent of Shanxi. The area is one of the major bases of the coal industry in China, as $54 \%$ of the land contains coal, accounting for as much as one-fifth of the total. There are three gasifiers (two operating and one spare) in the gasification workshop of the methanol plant. The amount of coal consumed by gasifiers per day is 3,000 tons with 900 tons of coal residual (include fly ash of 150 tons and coarse residual of 750 tons).

The samples were collected from the coal-tomethanol plant and were immediately stored in individual specially sealed plastic bags to avoid any oxidation and contamination. The appearance of the coal gasification residual samples was similar to the fly ash. Then the chemical compositions of the coal gasification residual samples were analyzed by $\mathrm{x}$-ray fluorescence spectrometry (XRF) (Table 1). A partial proximate analysis and mineralogy analysis of the samples were performed following the Chinese standard method GB212-2001 and powder x-ray diffraction (XRD), respectively (Table 2).The concentrations of elements in the leachate samples were determined by inductively coupled plasma-mass atomic spectrometry (ICP-MS) for $\mathrm{Hg}, \mathrm{Cr}, \mathrm{As}$, and $\mathrm{Pb}$, following the method described by Dai et al. (Table 3) [1].

Table 1. XRF analysis of coal gasification residual samples.

\begin{tabular}{|c|c|c|c|c|c|c|c|}
\hline & $\mathrm{CaO}$ & $\mathrm{SiO}_{2}$ & $\mathrm{Fe}_{2} \mathrm{O}_{3}$ & $\mathrm{C}$ & $\mathrm{Al}_{2} \mathrm{O}_{3}$ & $\mathrm{Na}_{2} \mathrm{O}$ & $\mathrm{MgO}$ \\
\hline Chemical Compositions (\%) & 30.08 & 20.12 & 18.17 & 16.12 & 8.23 & 2.14 & 1.93 \\
\hline
\end{tabular}


Table 2. Proximate analysis of fly ash and gasification residuals.

\begin{tabular}{|c|c|c|c|c|c|c|c|}
\hline Proximate analyses & $\mathrm{M}_{\mathrm{t}}(\%)$ & $\mathrm{M}_{\mathrm{ad}}(\%)$ & $\mathrm{V}_{\mathrm{ad}}(\%)$ & $\mathrm{A}_{\mathrm{ad}}(\%)$ & $\mathrm{FC}_{\mathrm{ad}}(\%)$ & $\mathrm{Q}_{\text {net,ar }}(\mathrm{kcal} / \mathrm{kg})$ & $\mathrm{Q}_{\mathrm{grad}}(\mathrm{kcal} / \mathrm{kg})$ \\
\hline Fly ash & 64.65 & 4.94 & 3.78 & 44.27 & 47.01 & 970 & 2,465 \\
\hline Gasification residual & 28.94 & 0.42 & 2.18 & 81.27 & 16.12 & 549 & 757 \\
\hline
\end{tabular}

$\mathrm{M}_{\mathrm{t}}$, total moisture; $\mathrm{M}_{\mathrm{ad}}$, moisture content, air dry basis; $\mathrm{V}_{\mathrm{ad}}$, volatile matter, air dry basis; $\mathrm{A}_{\text {ad, }}$ ash yield, air dry basis; $\mathrm{FC}_{\mathrm{ad}}$, fixed carbon, air dry basis; $\mathrm{Q}_{\text {net,ar }}$, net calorific value, received basis; $\mathrm{Q}_{\mathrm{gr}, \mathrm{ad}}$, calorific value, air dry basis

Table 3. Heavy metals of coal gasification residuals.

\begin{tabular}{|c|c|c|c|c|}
\hline Trace element & $\mathrm{Hg}$ & $\mathrm{Cr}$ & $\mathrm{As}$ & $\mathrm{Pb}$ \\
\hline Average Concentration $(\mathrm{mg} / \mathrm{kg})$ & 3.797 & 920.821 & 84.237 & 7.436 \\
\hline World Coal Gangue $[20]$ & $0.2-0.6$ & $50-160$ & $10-80$ & $10-40$ \\
\hline
\end{tabular}

\section{Leaching Experiments}

To investigate the influences of different $\mathrm{pH}$ values and sizes of coal gasification residual samples on the leaching behavior of the four heavy metals in the residual samples, we designed column leaching experimental groups for this study. The average $\mathrm{pH}$ of the rainfall in the study region is with no acid rain. According to the characteristics of the rainfall, distilled water $(\mathrm{pH}=7.0)$, acidic solution $(\mathrm{pH}=6.5)$, and alkaline solution $(\mathrm{pH}=7.5)$ were prepared as leaching media. And through screening and grinding, the coal gasification residual sample could be divided into three categories: 10 mesh, 40 mesh, and 80 mesh. Each coal gasification residual sample was transferred into a plastics column that was $40 \mathrm{~mm}$ internal diameter and $350 \mathrm{~mm}$ in length (Fig. 2). The flumes (with a capacity of two liters) were installed over the columns. There are six glass rotor flowmeters (LZB-2WB) between the infusion bottle and column to control the flow from $0.4 \mathrm{~mL} / \mathrm{min}$ to $4 \mathrm{~mL} / \mathrm{min}$.

In nature, leaching behavior of heavy metals in the soil is a long process. Hassett [18] thought that the experimental results of element concentration dynamics during leaching need to conduct a long-term leaching experiment. But it is difficult to simulate the leaching process in the laboratory under natural conditions for a long time. These experiments were designed to last for $96 \mathrm{~h}$ because the leaching reaction processes mainly happened in the initial leaching phase [19].

After screening, the samples of coal gasification residual were transferred into a fixed glass column $250 \mathrm{~mm}$ high. A small amount of absorbent cotton and much quartz sand to prevent fine particle loss was packed into the bottom of the column during the leaching. According to the rainfall of the study area, the outflow velocity of leaching solutions was controlled at $0.5 \mathrm{~mL} / \mathrm{min}$ by the tachometers. The resulting leachates were collected after $4 \mathrm{~h}, 8 \mathrm{~h}, 16 \mathrm{~h}, 24 \mathrm{~h}, 36 \mathrm{~h}, 48 \mathrm{~h}$, $72 \mathrm{~h}$, and $96 \mathrm{~h}$, collected $10 \mathrm{~mL}$ in a sealed container, and refrigerated at $4^{\circ} \mathrm{C}$ for analysis. The concentrations of elements in the resulting leachates were determined by inductively coupled plasma-mass atomic spectrometry (ICP-MS) for $\mathrm{Hg}, \mathrm{Cr}$, As, and $\mathrm{Pb}$.

\section{Results and Discussion}

\section{Chemistry and Mineralogy in the Residual Samples}

The coal gasification residual samples were analyzed by x-ray fluorescence spectrometry (XRF) (Table 1). The samples were dominated by $\mathrm{CaO}(30.08 \%)$ followed by $\mathrm{SiO}_{2}(20.12 \%), \mathrm{Fe}_{2} \mathrm{O}_{3}(18.17 \%)$, and unburned carbon $(16.12 \%)$, along with trace percentages of $\mathrm{Al}_{2} \mathrm{O}_{3}(8.23 \%)$, $\mathrm{Na}_{2} \mathrm{O}(2.14 \%)$, and $\mathrm{MgO}(1.93 \%)$.

The XRD patterns showed that the main minerals present in the coal gasification residual were calcite and quartz, accounting for $72 \%$ and $21 \%$, respectively. The coal gasification residuals had low calorific value $(757 \mathrm{kcal} / \mathrm{kg})$ and the calorific value of gasification residual was much lower than that of fly ash $(2,465 \mathrm{kcal} / \mathrm{kg})$ (Table 2). Because of low calorific value, there is no utilization and disposal methods for coal gasification residual.

The concentration of element $\mathrm{Pb}$ (the concentration equaled $7.436 \mathrm{mg} / \mathrm{kg}$ in the study area) was close to world Clarke Values and world Coal Gangue (Table 3). The remains of the selected trace elements in this study were enriched in comparison to the Clarke Values and Coal Gangue.

\section{Leaching Time}

Time is one of the most important factors affecting the leaching behavior of heavy metals from residuals [21]. Under different conditions, four different trends could be identified from Table 4, and all trends were in decreasing order of significance. The major trend was a sharp drop followed by decreased gradually or a steady curve as the leaching time went on. This trend was observed for elements $\mathrm{Cr}$, $\mathrm{As}$, and $\mathrm{Pb}$, accounting for $52.78 \%$ of all trends. Element $\mathrm{Hg}$ exhibited a slight and steady 


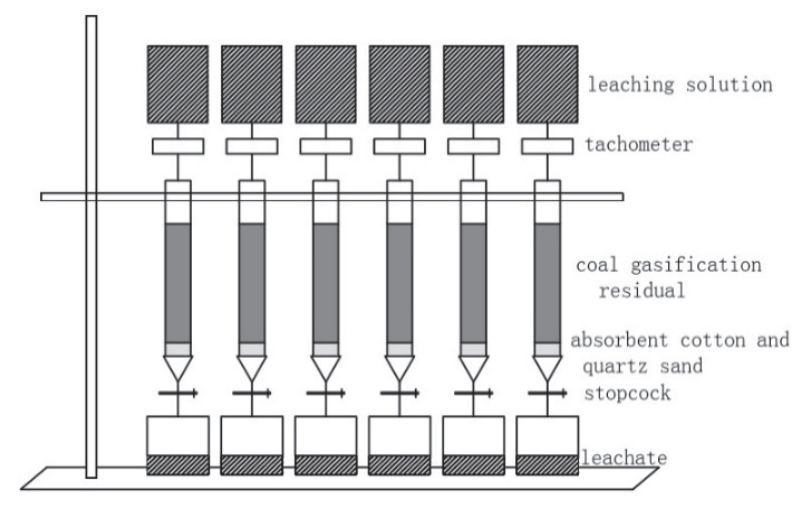

Fig. 2. System of dynamic leaching. decrease curve that contributed to $22.22 \%$. The slowsharp-slow drop and sharp-slow-sharp drop trend accounted for $16.67 \%$ and $8.33 \%$ of the trends, respectively.

The concentrations of the selected elements in the leachates reached the maximum at the initial leaching time periods [22]. Most leached concentrations reached the maximum at $0-4 \mathrm{~h}$, accounting for $94.44 \%$ of the leached concentrations. In the other periods of $4-8 \mathrm{~h}$ and 8-16 h, the resulting leachates reached the maximum concentration only twice: for $\mathrm{Hg}(40$ mesh, $\mathrm{pH}=7.5)$ and As ( 80 mesh, $\mathrm{pH}=7.5)$. The possible explanations of a higher extractable concentration at initial stages were as follows. The partial fraction of elements absorbed on

Table 4. Trace element concentrations in leachate $(\mu \mathrm{g} / \mathrm{L})$.

\begin{tabular}{|c|c|c|c|c|c|c|c|c|c|c|}
\hline \multirow{3}{*}{$\begin{array}{c}\text { Trace } \\
\text { elements }\end{array}$} & \multirow{3}{*}{$\begin{array}{c}\text { Leaching } \\
\text { time } / \mathrm{h}\end{array}$} & \multicolumn{3}{|c|}{$\mathrm{pH}=6.5$} & \multicolumn{3}{|c|}{$\mathrm{pH}=7.0$} & \multicolumn{3}{|c|}{$\mathrm{pH}=7.5$} \\
\hline & & \multicolumn{3}{|c|}{ Sample size } & \multicolumn{3}{|c|}{ Sample size } & \multicolumn{3}{|c|}{ Sample size } \\
\hline & & 10 mesh & 40 mesh & 80 mesh & 10 mesh & 40 mesh & 80 mesh & 10 mesh & 40 mesh & 80 mesh \\
\hline \multirow{9}{*}{$\mathrm{Hg}$} & 4 & 1.448 & 1.539 & 2.225 & 1.471 & 1.523 & 1.975 & 1.583 & 1.45 & 1.753 \\
\hline & 8 & 1.433 & 1.487 & 1.824 & 1.437 & 1.477 & 1.794 & 1.551 & 1.453 & 1.701 \\
\hline & 16 & 1.432 & 1.484 & 1.756 & 1.436 & 1.428 & 1.69 & 1.526 & 1.447 & 1.694 \\
\hline & 24 & 1.423 & 1.463 & 1.678 & 1.439 & 1.444 & 1.64 & 1.521 & 1.418 & 1.648 \\
\hline & 36 & 1.42 & 1.443 & 1.654 & 1.435 & 1.446 & 1.632 & 1.522 & 1.417 & 1.623 \\
\hline & 48 & 1.42 & 1.415 & 1.54 & 1.427 & 1.445 & 1.623 & 1.472 & 1.411 & 1.605 \\
\hline & 72 & 1.409 & 1.398 & 1.42 & 1.427 & 1.442 & 1.57 & 1.467 & 1.409 & 1.594 \\
\hline & 96 & 1.407 & 1.378 & 1.41 & 1.42 & 1.432 & 1.572 & 1.461 & 1.407 & 1.59 \\
\hline & & 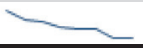 & 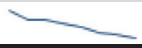 & 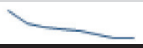 & $\sqrt{2}$ & 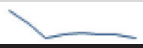 & $x$ & 2 & 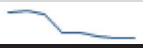 & $\gamma^{2}$ \\
\hline \multirow{9}{*}{$\mathrm{Cr}$} & 4 & 10.67 & 12.4 & 12.08 & 11.42 & 13.35 & 13.54 & 10.98 & 13.47 & 15.75 \\
\hline & 8 & 9.869 & 11.01 & 11.97 & 10.94 & 12 & 13.15 & 9.95 & 10.02 & 15.75 \\
\hline & 16 & 9.591 & 10.7 & 11.61 & 10.24 & 11.6 & 12.12 & 9.999 & 9.863 & 15.6 \\
\hline & 24 & 9.58 & 10.25 & 10.16 & 10.29 & 11.08 & 10.45 & 9.862 & 9.619 & 15.26 \\
\hline & 36 & 9.674 & 10.33 & 10.11 & 9.533 & 10.64 & 10.65 & 9.787 & 9.656 & 14.4 \\
\hline & 48 & 9.699 & 10.41 & 10.28 & 9.603 & 10.18 & 10.71 & 9.577 & 9.7 & 13.71 \\
\hline & 72 & 9.607 & 10.05 & 10.03 & 9.791 & 10.12 & 10.09 & 9.587 & 9.63 & 12.36 \\
\hline & 96 & 9.64 & 10.07 & 10.06 & 9.704 & 9.885 & 10.02 & 9.55 & 9.619 & 10.08 \\
\hline & & 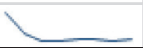 & 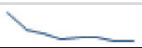 & $\longrightarrow$ & $\gamma$ & $\gamma$ & $>$ & 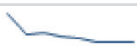 & $\checkmark$ & \\
\hline \multirow{9}{*}{ As } & 4 & 4.41 & 5.665 & 3.009 & 3.291 & 5.342 & 3.876 & 6.88 & 4.992 & 4.695 \\
\hline & 8 & 3.307 & 3.022 & 2.935 & 2.465 & 2.787 & 3.807 & 5.916 & 2.345 & 4.735 \\
\hline & 16 & 2.76 & 2.853 & 2.7 & 2.657 & 2.337 & 3.711 & 5.688 & 1.997 & 4.776 \\
\hline & 24 & 2.624 & 2.366 & 2.618 & 2.632 & 2.39 & 3.264 & 5.67 & 1.952 & 2.326 \\
\hline & 36 & 2.488 & 2.247 & 2.24 & 2.539 & 2.297 & 3.059 & 5.348 & 1.875 & 2.28 \\
\hline & 48 & 2.369 & 2.137 & 1.885 & 2.48 & 2.218 & 2.733 & 2.956 & 2.021 & 2.683 \\
\hline & 72 & 1.614 & 1.948 & 1.701 & 2.394 & 1.955 & 2.916 & 2.572 & 2.074 & 2.193 \\
\hline & 96 & 1.069 & 1.945 & 1.611 & 2.158 & 1.688 & 2.936 & 2.599 & 1.9 & 2.441 \\
\hline & & $x^{2}$ & 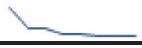 & 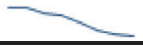 & $w$ & r & & $\longrightarrow$ & & 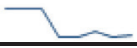 \\
\hline \multirow{9}{*}{$\mathrm{Pb}$} & 4 & 20.75 & 8.414 & 2.174 & 43.48 & 23.4 & 9.979 & 7.44 & 8.381 & 10.08 \\
\hline & 8 & 14.08 & 2.859 & 2.151 & 12.49 & 8.083 & 7.707 & 6.996 & 7.42 & 10 \\
\hline & 16 & 9.317 & 2.298 & 2.093 & 12.26 & 4.98 & 6.014 & 6.536 & 5.634 & 8.97 \\
\hline & 24 & 9.703 & 1.44 & 2.084 & 9.616 & 4.938 & 4.362 & 6.123 & 3.027 & 7.332 \\
\hline & 36 & 9.35 & 1.803 & 1.651 & 7.675 & 4.382 & 3.616 & 5.803 & 3.116 & 7.344 \\
\hline & 48 & 9.365 & 1.897 & 1.695 & 6.64 & 3.253 & 1.648 & 3.551 & 3.299 & 7.191 \\
\hline & 72 & 3.398 & 1.759 & 1.694 & 5.375 & 2.462 & 0.848 & 3.08 & 3.755 & 2.08 \\
\hline & 96 & 3.539 & 1.339 & 1.678 & 3.966 & 0.504 & 0.532 & 2.265 & 3.72 & 1.19 \\
\hline & & $\gamma$ & & $\checkmark$ & $\checkmark$ & V & $\gamma$ & 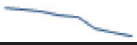 & $\gamma$ & $\longrightarrow$ \\
\hline
\end{tabular}


the surfaces or in the form of water-solution entered the solution easily. Then, as the leaching time went on, the concentrations of these elements on the surface and in the form of water-solution decreased gradually [21].

a)

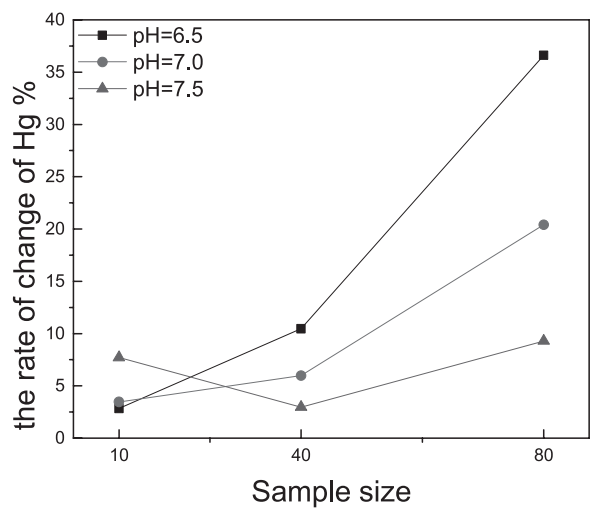

b)

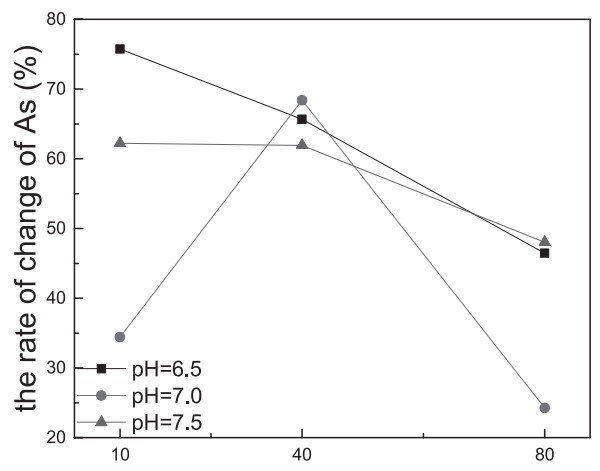

C)

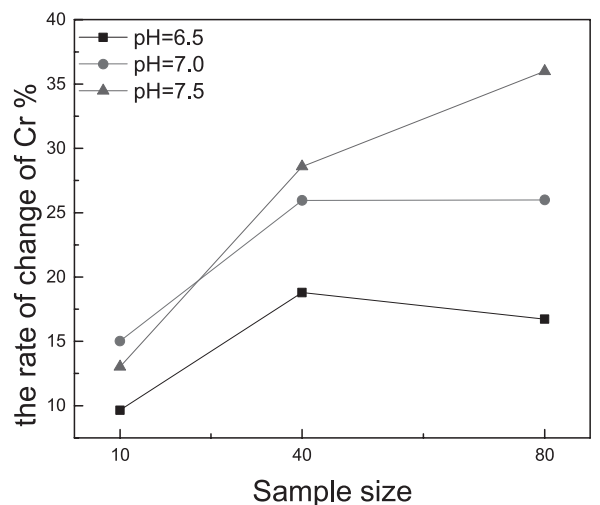

d)

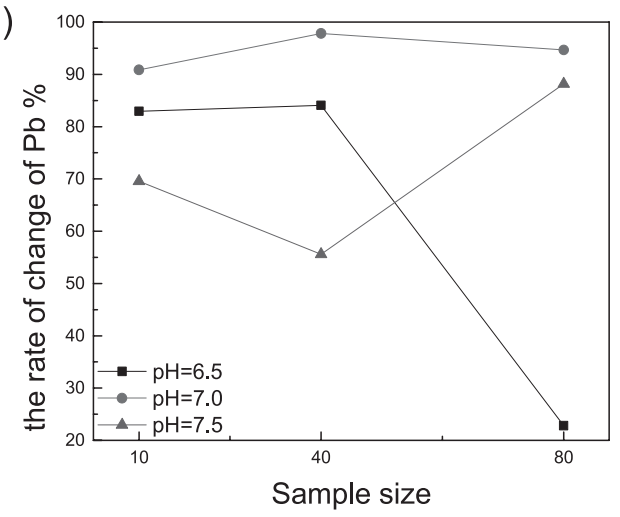

Fig. 3. Rate of change (\%) of the leached concentrations with the sample size.

\section{Size of Coal Gasification Residual}

For element $\mathrm{Hg}$, a slight and steady descending trend was a major curve type, except that the 80-mesh sample showed a sharp drop followed by a steady curve. And a sharp drop followed by a steady curve were observed for elements $\mathrm{Cr}$, As, and $\mathrm{Pb}$, except the all 80-mesh and some 10-mesh sample showed some other curve types (Table 4). Based on these trends, the 80-mesh sample had a different curve from the 10- and 40-mesh samples for the same element. The size of coal gasification residual was one of the most important factors affecting the leaching of heavy metals from residual samples. The reason this phenomenon happened was possibly that the different forms of the heavy metals existed on the different-sized samples, and the 80-mesh sample particles may have a specific surface.

The relationship between the rate of change of the leached concentrations and the sample size of coal gasification residual is shown in Fig. 3. For elements $\mathrm{Hg}$ and $\mathrm{Cr}$, the rate of change of concentrations were found to be reversely dependent on sample size, i.e., their change increased with the decreasing of the sample size as a whole. This was mainly because the mode of occurrence of elements $\mathrm{Hg}$ and $\mathrm{Cr}$ in the 80-mesh residual sample were easily dissolved into leaching solution.

When $\mathrm{pH}=6.5$ and 7.5 , the rate of change of concentrations of elements As were found to have their change decreased with the decreasing of the sample size as a whole. And when $\mathrm{pH}$ was $6.5,7.0$, and 7.5, the rate of change of the 80-mesh sample reached the minimum because the different mode of elements As occurred on small particles. For element $\mathrm{Pb}$, the rate of change could be kept to a higher level, reaching 50\% (except the 80 mesh sample at $\mathrm{pH}=6.5$ ).

The different form of the heavy metals existed on the different-sized samples [23-26]. And the element $\mathrm{Pb}$ was dissolved easily to reach a lower concentration in a short time. When $\mathrm{pH}=7.0$, the rate of change of the 40 -mesh residual sample could reach $94.85 \%$.

\section{$\mathrm{pH}$ of the Leaching Solution}

Previous studies have shown that the leaching behaviors of these elements are sensitive to $\mathrm{pH}$ of the leaching solution [27-29]. Considering the conditions of natural rainfall, three $\mathrm{pH}$ values - 6.5, 7.0, and 7.5 - were examined in this study. OriginPro software was used to calculate and draw the curves of the concentrations of the selected elements in the leachates to the leaching time. Then the areas under the curves were calculated as the leachability amount of the selected elements. The changes of leachability amount of the selected elements after $96 \mathrm{~h}$ are shown in Fig. 4.

For the 80 -mesh coal gasification residual, all selected elements showed minimum leachability at $\mathrm{pH}=6.5$, although between $\mathrm{pH}=7.0$ and 7.5 it did not follow any obvious regular patterns. A possible explanation was that 
the form of heavy metals could not be easily dissolved in acid solution.

For the 40-mesh coal gasification residual, the leachability amount of elements $\mathrm{Hg}$ and $\mathrm{Cr}$ showed a

a)

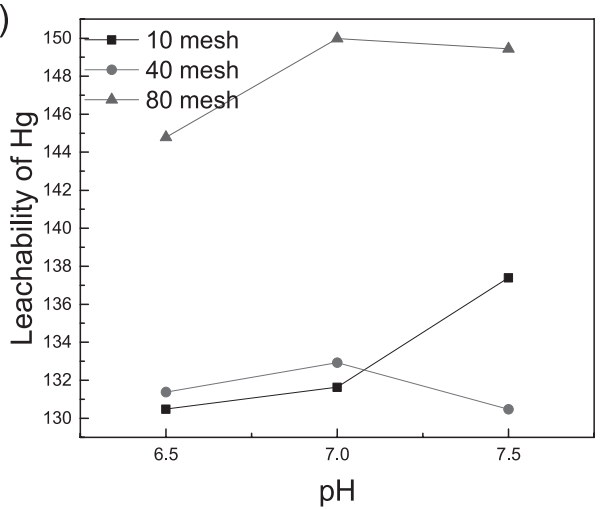

b)

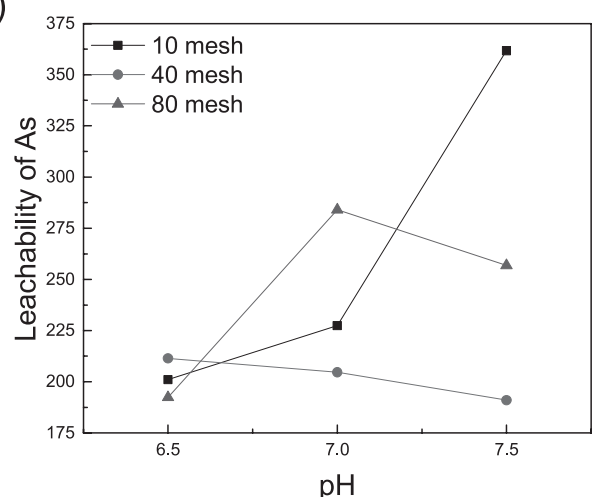

c)

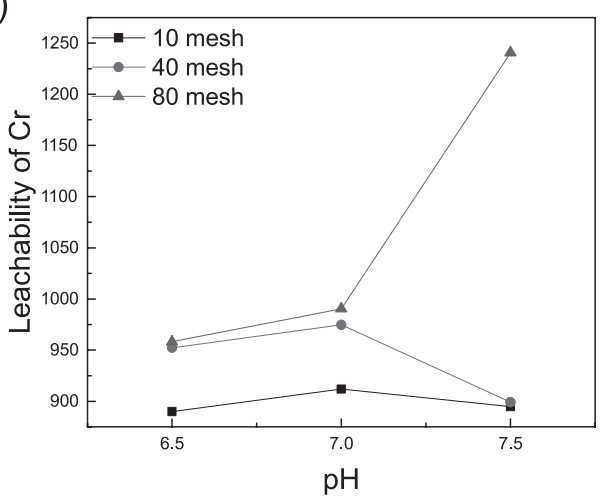

d)

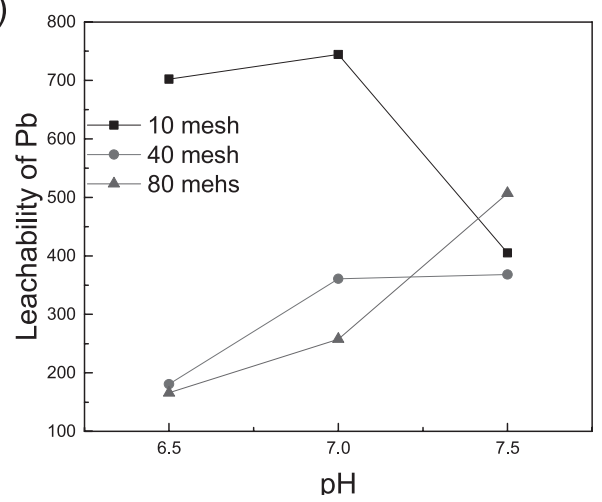

Fig. 4. Leachabilities amount of the four elements from coal gasification residual with $\mathrm{pH}$ after $96 \mathrm{~h}$. maximum leachability at $\mathrm{pH}=7.0$. The leachability of As decreased with increasing $\mathrm{pH}$. $\mathrm{Pb}$ showed a minimum leachability at $\mathrm{pH}=6.5$, and there was no significant change of leachability amount at $\mathrm{pH}=7.0$ and 7.5.

For the 10-mesh coal gasification residual, the leachabilities of $\mathrm{Hg}$ and $\mathrm{As}$ increased with the increasing $\mathrm{pH}$ and attached to a maximum leachablity at $\mathrm{pH}=7.5$. The minimum leachability of element $\mathrm{Pb}$ was shown at $\mathrm{pH}=7.5$. And the leachability of $\mathrm{Cr}$ had no significant changes under different $\mathrm{pH}$ values.

In general, there was no significant variation rules for the $\mathrm{pH}$ values and the leachabilities of the elements from the coal gasification residual. But considerable changes of the amount of leachabilities were experienced with the change of $\mathrm{pH}$ of leaching solution. The results indicated that the $\mathrm{pH}$ values could influence leaching behavior.

\section{Conclusions}

- As the leaching time went on, all trends were in decreasing order of significance. Of them, the major trend was a sharp drop followed by decreased gradually or a steady curve accounting for $52.78 \%$ of all trends. And most leached concentrations reached the maximum at the initial stage of leaching experiments (from hours 0 to 4 ).

- The size of the residual sample was one of the impact factors for the leaching behavior of the elements. The different form of the heavy metals existed on the different-size sample. When $\mathrm{pH}=7.0$, the rate of change of the 40-mesh residual sample could reach $94.85 \%$.

- In general, there were no significant variation rules for the $\mathrm{pH}$ values and the leachabilities of the elements from the coal gasification residual, but $\mathrm{pH}$ played an important role in leaching behavior.

\section{Acknowledgements}

This study was supported by the National Natural Science Fund of China (No. 41601336), the National Basic Research Program of China (973 Program, No. 2014CB238906), and the Beijing Natural Science Fund (Development of heavy metal immobilization agents and its control mechanism in the process of urban sewage sludge amended sandy soil, No. 8152025).

\section{References}

1. DAI S., REN D., CHOU C.-L., FINKELMAN R.B., SEREDIN V.V., ZHOU Y. Geochemistry of trace elements in Chinese coals: A review of abundances, genetic types, impacts on human health, and industrial utilization. International Journal of Coal Geology, 94, 3, 2012.

2. LIANG Y., LIANG H., ZHU S. Mercury emission from spontaneously ignited coal gangue hill in Wuda coalfield, Inner Mongolia, China. Fuel, 182, 525, 2016. 
3. GE H., FENG Y., LI Y., YANG W., GONG N. Heavy metal pollution diagnosis and ecological risk assessment of the surrounding soils of coal waste pile at Naluo Coal Mine, Liupanshui, Guizhou. International Journal of Mining Reclamation and Environment, 30 (4), 312, 2016.

4. ACOSTA A., AINETO M., IGLESIAS I., ROMERO M., RINCON J.M. Physico-chemical characterization of slag waste coming from GICC thermal power plant. Materials Letters, 50 (4), 246, 2001.

5. WU T., GONG M., LESTER E., WANG F., ZHOU Z., YU, $Z$. Characterisation of residual carbon from entrained-bed coal water slurry gasifiers. Fuel, 86 (7-8), 972, 2007.

6. MATJIE R.H., VAN ALPHEN, C. Mineralogical features of size and density fractions in Sasol coal gasification ash, South Africa and potential by-products. Fuel, 87 (8-9), 1439, 2008.

7. WAGNER N.J., MATJE R.H., SLAGHUIS J.H., VAN HEERDEN J.H.P. Characterization of unburned carbon present in coarse gasification ash. Fuel, 87 (6), 683, 2008.

8. YANG L., SONG J., BAI X., SONG B., WANG R., ZHOU T., JIA J., PU H. Leaching Behavior and Potential Environmental Effects of Trace Elements in Coal Gangue of an Open-Cast Coal Mine Area, Inner Mongolia, China. Minerals, 6 (2), 2016.

9. CELIK K., MERAL C., GURSEL A.P., MEHTA P.K., HORVATH A., MONTEIRO P.J.M. Mechanical properties, durability, and life-cycle assessment of self-consolidating concrete mixtures made with blended portland cements containing fly ash and limestone powder. Cement \& Concrete Composites, 56, 2015.

10. JUNAID M.T., KAYALI O., KHENNANE A. Response of alkali activated low calcium fly-ash based geopolymer concrete under compressive load at elevated temperatures. Materials and Structures, 50 (1), 2017.

11. KOVLER K. Does the utilization of coal fly ash in concrete construction present a radiation hazard? Construction and Building Materials, 29, 158, 2014.

12. MARAGHECHI H., SALWOCKI S., RAJABIPOUR F. Utilisation of alkali activated glass powder in binary mixtures with Portland cement, slag, fly ash and hydrated lime. Materials and Structures, 50 (1), 14, 2017.

13. AHMARUZZAMAN M. A review on the utilization of fly ash. Progress in Energy and Combustion Science, 36 (3), 327, 2010.

14. WANG S.B., LI L., WU H.W., ZHU Z.H. Unburned carbon as a low-cost adsorbent for treatment of methylene bluecontaining wastewater. Journal of Colloid and Interface Science, 292 (2), 336, 2005.

15. BANERJEE S.S., JAYARAM R.V., JOSHI M.V. Removal of nickel (II) and zinc (II) from wastewater using fly ash and impregnated fly ash. Separation Science and Technology, 38 (5), 1015, 2003.

16. AKSU Z., YENER J. A comparative adsorption/biosorption study of mono-chlorinated phenols onto various sorbents. Waste Management, 21 (8), 695, 2001.

17. YANG L., WANG F.Z., HAKKI A., MACPHEE D.E., LIU, P., HU S.G. The influence of zeolites fly ash bead/TiO, composite material surface morphologies on their adsorption and photocatalytic performance. Applied Surface Science, 392, 687, 2017.
18. HASSETT D.F, EYLANDS K.E., WEBER G.F. Assessment of residues from duct injection demonstration site. Journal of the Air \& Waste Management Association. 44 (10), 1214, 1994.

19. TANG J., STEENARI B.M. Leaching optimization of municipal solid waste incineration ash for resource recovery: A case study of $\mathrm{Cu}, \mathrm{Zn}, \mathrm{Pb}$ and $\mathrm{Cd}$. Waste Management, 48, $315,2016$.

20. HOWER J.C., ROBL T.L., ANDERSON C., THOMAS G.A., SAKULPITAKPHON T., MARDON S.M., CLARK W.L. Characteristics of coal combustion products (CCP's) from Kentucky power plants, with emphasis on mercury content. Fuel, 84, 1338, 2005.

21. WANG W., QIN Y., SONG D., WANG K. Column leaching of coal and its combustion residues, Shizuishan, China. International Journal of Coal Geology, 75 (2), 81, 2008.

22. PANDA S., MISHRA G., SARANGI C.K., SANJAY K., SUBBAIAH T., DAS S.K., SARANGI K., GHOSH M.K., PRADHAN N., MISHRA B.K. Reactor and column leaching studies for extraction of copper from two low grade resources: A comparative study. Hydrometallurgy, 165, 111, 2016.

23. DELGADO J., BARBA-BRIOSO C., MIGUEL NIETO J., BOSKI T. Speciation and ecological risk of toxic elements in estuarine sediments affected by multiple anthropogenic contributions (Guadiana saltmarshes, SW Iberian Peninsula): I. Surficial sediments. Science of the Total Environment, 409 (19), 3666, 2011.

24. SHANG W., TANG Q., ZHENG L., CHENG H. Chemical forms of heavy metals in agricultural soils affected by coal mining in the Linhuan subsidence of Huaibei Coalfield, Anhui Province, China. Environmental Science and Pollution Research, 23 (23), 23683, 2016.

25. CHEN F., HU Y., DOU X., CHEN D., DAI, X. Chemical forms of heavy metals in pyrolytic char of heavy metalimplanted sewage sludge and their impacts on leaching behaviors. Journal of Analytical and Applied Pyrolysis, 116, $152,2015$.

26. SAQIB N., BACKSTROM M. Chemical association and mobility of trace elements in 13 different fuel incineration bottom ashes. Fuel, 172, 105, 2016.

27. KOMONWEERAKET K., CETIN B., BENSON C.H., AYDILEK A.H.,EDIL T.B. Effects of $\mathrm{pH}$ on the leaching mechanisms of elements from fly ash mixed soils. Fuel, 140, 788, 2015.

28. Zhang Y., CETIN B., LIKOS W.J., EDIL T.B. Impacts of $\mathrm{pH}$ on leaching potential of elements from MSW incineration fly ash. Fuel 184, 815, 2016.

29. STEFANIAK S., KMIECIK E., MISZCZAK E., SZCZEPANSKA-PLEWA J., TWARDOWSKA I. Effect of weathering transformations of coal combustion residuals on trace elements mobility in view of the environmental safety and sustainability of their disposal and use. II. Element release. Journal of Environmental Management, 156, 167, 2015. 